\title{
ACEITAÇÃO E RENÚNCIA DE HERANÇA: RELEVÂNCIA E QUESTÕES CONTROVERTIDAS
}

\author{
ACCEPTANCE AND WAIVER OF INHERITANCE: RELEVANCE AND CONTROVERSIAL ISSUES
}

Danilo Haddad Jafet*

\begin{abstract}
Resumo:
À primeira vista, a aceitação e a renúncia de herança podem parecer institutos sem muita utilidade prática no Direito Contemporâneo. De um lado, o Código Civil prestigiou o princípio da saisine, que torna automática a transferência da herança aos herdeiros, no momento da morte. De outro, também por força legal, o herdeiro não responderá por encargos superiores à força da herança. Este artigo analisará a relevância das figuras, além de conceituá-las e discutir questões controvertidas como sua natureza jurídica e a necessidade de outorga conjugal na renúncia.
\end{abstract}

Palavras-chave: Aceitação. Renúncia. Herança. Sucessão. Outorga conjugal.

\begin{abstract}
:
At first glance, acceptance and waiver of inheritance may seem not very useful issues in Contemporary Law. On one hand, the Brazilian Civil Code adopted the saisine principle, through which the inheritance is automatic transferred to the inheritors at the time of death. On the other hand, Law also provides that the inheritors shall not be liable for debts greater than the inheritance asset. The main purpose of this paper is the analysis of the relevance of both legal institutions, as well as to draft their frameworks and, finally, the analysis of controversial issues, such as the legal nature and the need of marital consent to waive the inheritance.
\end{abstract}

Keywords: Acceptance. Waiver. Inheritance. Succession. Marital consent.

Introdução

Com o presente artigo, pretende-se realizar estudo aprofundado dos institutos da aceitação e da renúncia de herança. Para tanto, primordial se mostra entender a sistemática adotada pelo ordenamento jurídico brasileiro para que se opere a transmissão de titularidade dos bens e direitos que compõem o acervo sucessório do falecido para o patrimônio individual de cada um de seus herdeiros.

Em seguida, terá início o exame do instituto da aceitação de herança, que merece ser estudado antes da renúncia, porque é a regra geral. O primeiro questionamento envolve a sua real utilidade face ao princípio da saisine. Respondida esta questão, relevante

* Danilo Haddad Jafet é advogado, formado pela Faculdade de Direito da Universidade de São Paulo e mestrando em Direito Civil pela mesma instituição (jafet_d@yahoo.com.br). 
definir sua natureza jurídica, bastante controvertida na doutrina, para, finalmente, traçar suas principais características.

$\mathrm{O}$ estudo da renúncia da herança merece um enfoque histórico para que se entenda a importância do instituto ao longo do tempo, inclusive nos dias de hoje, em que pode soar bastante estranho renunciar à herança para a maioria dos brasileiros. As características do instituto também serão abordadas e analisadas. Por fim, vale examinar uma das questões mais controvertidas que o tema envolve: a necessidade de outorga conjugal.

\section{Forma de aquisição da herança}

Com a morte, a herança transmite-se desde logo aos herdeiros do falecido, de forma automática. Trata-se de ficção jurídica adotada por diversos ordenamentos, incluindo-se o brasileiro, para evitar a existência de qualquer hiato temporal em que os bens que compõem a herança ficariam sem titularidade. Desse modo, a partir do momento da morte do autor da herança, seus herdeiros legítimos e testamentários passam a ter o domínio e a posse sobre todos os bens de propriedade do falecido. Este fato jurídico não exige qualquer formalidade e sequer demanda que os herdeiros tenham conhecimento de sua condição de sucessores. Pelo contrário, até o herdeiro que estiver em local incerto e não sabido será titular da porção do acervo que lhe couber. É o consagrado droit de saisine. ${ }^{1}$

Nesse sentido, o art. 1.784 do Código Civil de 2002 - que praticamente reproduziu o conteúdo do art. 1.572 do Código Civil de 1916 - preceitua que "aberta a sucessão, a herança transmite-se, desde logo, aos herdeiros legítimos e testamentários". Todos os bens são transmitidos em conjunto, como uma universalidade indivisível, sobre a qual todos os herdeiros exercem uma espécie de condomínio forçado, na proporção de suas partes ideais, até o momento da partilha de bens, em que o patrimônio se dividirá e se distribuirá aos herdeiros, respeitadas as frações de seus quinhões ideais.

Da abertura da sucessão até o término do inventário, qualquer herdeiro terá direito de reclamar a universalidade da herança em face de terceiros que, eventualmente, estejam na posse injusta de qualquer dos bens que compõem o acervo sucessório.

Deve ficar claro que, até a partilha, não é conferido ao herdeiro direito à propriedade ou à posse exclusiva de qualquer dos bens. Ele é condômino e compossuidor,

$1 \quad$ Hironaka (2014, p. 376) ensina que o droit de saisine nasceu para corrigir uma injustiça: com a morte dos vassalos franceses, as propriedades exploradas por eles eram devolvidas aos senhores feudais. Para reavêlas, os herdeiros do vassalo falecido eram obrigados a indenizar o senhor feudal. Passou-se a adotar a ficção de que, no momento de sua morte, o vassalo teria imitido seus herdeiros na posse de todos os seus bens. 
podendo exercer atos possessórios sobre o todo unitário e indivisível, na medida em que não excluir os mesmos direitos dos outros herdeiros.

$\mathrm{O}$ ordenamento jurídico brasileiro estabeleceu dois momentos no tocante à transmissibilidade da herança. Como já dito, em um primeiro momento, tem-se a transmissão automática da propriedade operada pelo droit de saisine, que ocorre de forma peremptória. Contudo, para que esta transmissão seja considerada definitiva, há que se dar a aceitação da herança pelo herdeiro, que, em um segundo momento, confirmará concretamente a situação provisória antes estabelecida abstratamente.

\section{Aceitação de herança}

A aceitação da herança é o ato pelo qual o herdeiro ou o legatário confirma seu desejo de receber a herança ou o legado. ${ }^{2}$ Diante da transmissão automática havida com a morte do de cujus, é natural o surgimento do questionamento acerca da real importância da aceitação, que não é o fato gerador da aquisição hereditária (GOMES, 1986, p. 22). Nesse caso, não haveria razão para conceder ao herdeiro as faculdades de aceitação e renúncia da herança, mas apenas a segunda, tendo em vista que a transmissão dos bens se dá imediatamente com a morte.

A necessidade da aceitação se explica pelo fato de que ninguém é obrigado a ser herdeiro, não sendo lícito impor, contra a vontade do sujeito, todas as obrigações e encargos advindos do recebimento de herança. Pode-se dizer, então, que a aceitação é a confirmação concreta e definitiva da transmissão abstrata dada com a abertura da sucessão, solidificando e perpetuando a situação originariamente provisória. Por isso mesmo, o conteúdo da aceitação é declaratório e tem efeitos retroativos ao momento da abertura da sucessão, nos termos do art. 1.804 do Código Civil.

\subsection{Características da aceitação}

A doutrina diverge quanto à natureza jurídica da aceitação e, por consequência, da renúncia da herança. Duas são as correntes que se posicionam sobre o tema. A primeira acredita que se está diante de negócios jurídicos unilaterais, enquanto a segunda defende se tratar de atos jurídicos stricto sensu. ${ }^{3}$ Para Miranda (2012, tomo 3,

Tartuce e Simão (2013, p. 40) esclarecem que todas as regras relativas à aceitação e à renúncia de herança se aplicam, também, à aceitação e à renúncia de legado.

3 Vale transcrever trecho da obra de Pontes de Miranda, para que fique mais clara a diferenciação entre negócio jurídico, de um lado, e ato jurídico stricto sensu, de outro: "A presente função do conceito de negócio jurídico está em servir à distinção entre negócio jurídico e ato jurídico não-negocial ou stricto sensu, naqueles casos em que o suporte fáctico do ato jurídico stricto sensu consiste em manifestação de vontade. Frisemo-lo bem: manifestação de vontade; para que não incorramos no erro de definirmos como 
p. 57), a aceitação e a renúncia da herança são negócios jurídicos unilaterais. Entende o jurista que "não seria de admitir-se que não produzissem negócio jurídico atos humanos adeclarativos, em que há vontade de negócio, como: aceitação da herança (...)". ${ }^{4}$

Após fazer a distinção entre ato jurídico em sentido estrito e negócio jurídico unilateral, Borghi (1977, p. 77-78) conclui que "fica, pois, bem definida a natureza jurídica da renúncia sucessória, pela predominância dos elementos vontade e objeto, totalmente independentes de anterior ordenamento jurídico, essenciais para sua devida caracterização como negócio jurídico”. Compartilham deste entendimento Zeno Veloso 5 e Orlando Gomes (GOMES, 1986, p. 24).

De outro lado, José Fernando Simão e Flávio Tartuce entendem que " $a$ aceitação é ato jurídico em sentido estrito (stricto sensu), e não negócio jurídico, pois seus efeitos decorrem somente da lei e não da convenção das partes". ${ }^{6}$ Parecem corroborar com esta corrente Hironaka (2003, p. 116) Cahali (CAHALI; HIRONAKA, 2007, p. 70) e Diniz (2014, p. 64). Os três autores definem a aceitação e a renúncia da herança como atos jurídicos unilaterais, sem especificar de forma indubitável se, de fato, estariam se referindo a atos jurídicos em sentido estrito. ${ }^{7}$

Expostos os dois posicionamentos adotados pela doutrina, parece mais adequado classificar a aceitação e a renúncia da herança como atos jurídicos stricto sensu. Não se vê, aqui, a manifestação suprema da autonomia privada, que caracteriza tão bem os negócios jurídicos. Pelo contrário, ao invés da vontade qualificada de autorregulamentação dos interesses do sujeito, verifica-se apenas um mero ato de vontade do aceitante ou do renunciante da herança, cujos efeitos são preordenados pelos dispositivos contidos no Código Civil. Em outras palavras, quem aceita ou renuncia à herança não tem a faculdade de escolher o conteúdo ou o efeito do ato: sua única escolha é aceitar ou renunciar. Os

coextensivos, superponíveis de modo completo, a manifestação de vontade (suporte fáctico) e o negócio jurídico, que é apenas uma das classes dos atos jurídicos em que há, como elemento fáctico, manifestação de vontade. O conceito surgiu exatamente para abranger os casos em que a vontade humana pode criar, modificar ou extinguir direitos, pretensões, ações ou exceções, tendo por fito êsse acontecimento do mundo jurídico. Naturalmente, para tal poder fático de escolha supõe-se certo auto regramento de vontade, dito 'autonomia da vontade', por defeito de linguagem (nomos é lei); com êsse auto regramento, o agente determina as relações jurídicas em que há de figurar como termo" (MIRANDA, 2012, tomo 3, p. 55).

4 Além disto, ao fazer análise dos negócios jurídicos unilaterais, Miranda (2012, tomo 3, p. 215-220) dedica cerca de seis páginas ao estudo da renúncia.

5 "Muita gente confunde cessão de direitos hereditários com renúncia de herança. Esta última é negócio jurídico unilateral, tratando-se de uma demissão de direito, sendo sempre abdicativa” (VELOSO, 2008).

6 E, ao estudar a renúncia, prosseguem os mestres: "como ocorre com a aceitação, a renúncia da herança também tem natureza de ato jurídico em sentido estrito (stricto senso), pois os seus efeitos decorrem apenas da norma jurídica, e não da vontade do renunciante (...)" (TARTUCE; SIMÃO, 2013, p. 40, 44-45).

7 Esta ressalva merece ser feita para o caso de os juristas adotarem a classificação sugerida por Miranda (2012, tomo 3, p. 204), para quem o grupo dos atos jurídicos unilaterais englobaria tanto os atos jurídicos stricto sensu quanto os negócios jurídicos unilaterais: "Se alguém, que tem que ser assistido, pratica algum ato jurídico unilateral (ato jurídico stricto sensu ou negócio jurídico) (...)”. 
efeitos dela decorrentes não são dados pelo agente, mas predeterminados pelo ordenamento jurídico.

Os incapazes poderão aceitar a herança quando representados por tutor ou curador, mediante autorização judicial prévia, nos termos do art. 1.748, inciso II, do Código Civil. Também é lícita a aceitação dada pelo mandatário ou pelo gestor de negócios. Em todos estes casos se estará diante de aceitação direta, feita em nome do sucessor. Frise-se, ademais, que a lei não exige outorga conjugal para que o herdeiro manifeste a intenção de aceitar a herança.

São três as formas de aceitação da herança, a expressa, a tácita e a presumida. Nos termos do art. 1.805 do Código Civil, a aceitação será expressa se realizada por meio de declaração escrita, clara e inequívoca. Note-se que não há exigência alguma quanto à forma do instrumento escrito, sendo admitida tanto a aceitação por instrumento público quanto a expressa por instrumento particular. Não poderá, contudo, ser verbal a aceitação expressa, ou seja, não admite prova meramente testemunhal.

O mesmo dispositivo legal admite a aceitação tácita, quando resultante de "atos próprios da qualidade de herdeiro". Aceita tacitamente a herança o herdeiro que pratica atos que somente quem ostenta a qualidade de herdeiro tem legitimidade para praticar, que indicam aceitação, de um lado, e são incompatíveis com a renúncia, de outro. A doutrina dá exemplos diversos de atos que indicam aceitação tácita da herança, tais como aqueles definitivos de administração do espólio ou dos bens do falecido, nomeação de advogado para defender os interesses do sujeito, promessa de venda de bens que compõem o acervo sucessório, imissão na posse efetiva de bens do acervo sucessório, pagamento de impostos incidentes sobre referidos bens, entre outros.

O parágrafo primeiro do art. 1.805 do Código Civil determina que não configuram aceitação tácita os atos oficiosos praticados pelo herdeiro, tais como a promoção do funeral do falecido, bem como os de administração provisória, ou meramente conservatórios dos bens deixados pelo de cujus, para atender a situações de urgência, por exemplo. São casos em que, mais do que agir por legítimo interesse de se confirmar herdeiro, a pessoa age por consideração ao falecido ou a seus familiares, movida pelo espírito de solidariedade. Por fim, na dicção do parágrafo segundo, não importa aceitação a cessão gratuita, pura e simples, da herança aos demais coerdeiros. Aqui, a lei quer dizer, de forma pouco técnica, que a renúncia não configura aceitação tácita, o que é bastante óbvio e não precisaria sequer ser dito. ${ }^{8}$

\footnotetext{
8 A lei fala em cessão gratuita da herança aos demais coerdeiros, cujo efeito é exatamente o da renúncia à herança, porque a ordem natural é que o quinhão renunciado retorne ao monte mor para distribuição proporcional entre os demais coerdeiros. Tartuce e Simão apontam o entendimento de renomados juristas, como Zeno Veloso, Clóvis Beviláqua, Eduardo de Oliveira Leite e José Luiz Gavião de Almeida, neste sentido (TARTUCE; SIMÃO, 2013, p. 42).
} 
O Código Civil de 2002, assim como seu antecessor, não estabeleceu prazo para aceitação da herança. Desse modo, os interessados em que o herdeiro se pronuncie pela aceitação, ou não, podem, passados 20 dias da abertura da sucessão, requerer ao juiz abrir prazo razoável, não superior a 30 dias, para que o herdeiro se manifeste. No silêncio, presume-se a aceitação da herança. A esta hipótese, a doutrina dá o nome de aceitação presumida da herança.

São possíveis interessados os demais coerdeiros, aqueles que seriam os próximos na ordem de sucessão e os credores do herdeiro. Os coerdeiros são interessados no pronunciamento do herdeiro porque, caso ele opte por não aceitar a herança, renunciando a ela, seu quinhão volta ao monte mor para ser redistribuído proporcionalmente entre os coerdeiros. Caso não haja coerdeiros, a herança renunciada será destinada àqueles que seriam os próximos na ordem de sucessão, como ficará evidenciado oportunamente, o que justifica, também, seu interesse na manifestação do herdeiro. Por fim, em sentido contrário, aos credores do herdeiro interessa que ele aceite a herança, porque assim poderá empregar os bens recebidos para quitar seus débitos.

$\mathrm{O}$ direito de aceitação da herança não é personalíssimo. Pelo contrário, nos termos do art. 1.809 do Código Civil, em caso de falecimento do herdeiro antes de declarar se aceita ou não a herança, o poder de fazê-lo é transferido aos seus sucessores, exceto se a herança tiver sido instituída sob condição suspensiva não verificada até o falecimento do herdeiro. Isto se explica pelo fato de que os sucessores só passariam a ser titulares do direito de aceitação se ele já integrasse o patrimônio do falecido no momento da morte. Se a condição não for verificada até o referido momento, o direito não terá sido adquirido pelo herdeiro e, por isto mesmo, não poderá ser transferido a seus sucessores.

Para que os sucessores do herdeiro falecido possam exercer o direito de aceitar ou de renunciar à herança que caberia a ele, devem, antes, aceitar a herança deixada pelo herdeiro falecido antes de aceitá-la. Explica-se de forma mais cautelosa: aqui se está a falar de duas heranças: (i) a herança deixada pelo primeiro falecido, cujo direito de aceitação pertencia ao herdeiro que veio a falecer antes de exercê-lo (a "herança do primeiro de cujus"); e (ii) a herança do herdeiro que faleceu antes de aceitar a herança do primeiro de cujus (a "herança do herdeiro pós-morto", cujo direito de aceitação pertence aos seus sucessores).

Os sucessores do herdeiro pós-morto só poderão aceitar ou renunciar à herança do primeiro de cujus se antes tiverem aceitado a herança do herdeiro pós-morto, por um motivo muito simples: o direito de aceitar ou renunciar à herança do primeiro de cujus integra o patrimônio deixado pelo herdeiro pós-morto aos seus sucessores. Se eles não aceitarem sua herança, não haverá transferência da titularidade do direito de aceitação ou renúncia da herança do primeiro de cujus. Note-se que, neste caso, os sucessores do herdeiro pós-morto herdam por estirpe, porque o estão representando na sucessão do 
primeiro de cujus. Assim, o quinhão que será dividido igualmente entre os herdeiros do herdeiro pós-morto deverá ser igual aos quinhões dos demais herdeiros do primeiro de cujus.

\subsection{Características da aceitação também presentes na renúncia}

Até o momento, foram traçados os principais contornos do instituto da aceitação da herança, que o individualizam. Existem, contudo, algumas características comuns à aceitação e à renúncia, que poderiam ser tratadas ao final deste artigo. Por opção metodológica, este artigo fará o estudo ininterrupto da figura da aceitação para, em seguida, fazer o mesmo com a figura da renúncia. Esclarece-se que tudo o que será abordado neste subitem também será aplicável à figura da renúncia e, portanto, para evitar repetições, no tópico próprio ao estudo da renúncia, estas características serão apenas referenciadas, porquanto já terão sido explicadas aqui.

Prosseguindo, é importante mencionar que a aceitação não depende de comunicação a terceiros, dispensando a anuência ou a concordância dos demais herdeiros para que produza efeitos, portanto trata-se de figura não receptícia.

Ademais, atualmente, a aceitação é um ato jurídico irretratável, definitivo e irrevogável, o que importa dizer que não comporta arrependimento. Não era assim enquanto vigente o Código Civil de 1916, que admitia a retratação da aceitação, desde que disto não resultasse qualquer prejuízo aos credores do herdeiro, e a retratação da renúncia, quando proveniente de violência, erro ou dolo. Parece mais adequada a regra disposta no atual diploma civil, que prestigia a segurança jurídica. Dependendo do momento da retratação da aceitação, ela poderia conturbar gravemente o bom andamento do processo de inventário, por exemplo. De outro lado, a regra que possibilitava a retratação da renúncia em casos de vício de consentimento era desnecessária, porque atos jurídicos eivados destes defeitos são anuláveis em razão do disposto no art. 171 do Código Civil de 2002 (TARTUCE; SIMÃO, 2013, p. 55).

A aceitação da herança não pode se dar em partes, conforme preceitua o art. 1.808 do Código Civil. Até que haja a partilha, no término do processo de inventário, a herança é tida como uma universalidade indivisível de direitos. ${ }^{9}$ Assim, ou o herdeiro aceita a totalidade do quinhão hereditário a ele destinado, ou não aceita herança alguma. É defeso ao herdeiro escolher certos bens para herdar e repudiar outros, ou, então, aceitar

Nos termos do art. 1.791 do Código Civil: "A herança defere-se como um todo unitário, ainda que vários sejam os herdeiros. Parágrafo único. Até a partilha, o direito dos co-herdeiros, quanto à propriedade e posse da herança, será indivisivel, e regular-se-á pelas normas relativas ao condomínio". 
os créditos da herança e rejeitas os débitos. Esta regra também serve como garantia de que a herança servirá para quitar os débitos de seu autor, desde que nos limites da sua força.

Devem ser feitas duas ressalvas quanto à regra da indivisibilidade da aceitação - que também se aplica para a renúncia, ou seja, ninguém pode renunciar a apenas parcela da herança -, ambas contidas nos parágrafos do art. 1.808. Não se estará diante de aceitação parcial em casos de diversidade de causas sucessórias. Assim, se um herdeiro tiver direito à herança e a um legado deixado pelo autor da herança, poderá aceitar o legado e rejeitar a herança ou aceitar a herança e rejeitar o legado. Aqui não se fere a indivisibilidade da herança, porque o legado já é uma individualização permitida por lei. Do mesmo modo, se um herdeiro tiver direito a um quinhão pela legítima e a outro quinhão por herança testamentária, ele poderá aceitar um dos quinhões e rejeitar o outro.

Por fim, ainda nos termos do art. 1.808 do Código Civil, a aceitação deve ser pura e simples. Não se admite aceitação da herança sob condição ou termo, ou seja, não pode ela ser subordinada a eventos futuros e incertos ou futuros e certos, para evitar insegurança jurídica.

\section{Renúncia de herança}

A renúncia é uma "deixação de direito expectativo" (MIRANDA, 2012, tomo 3, p. 216). Ainda segundo Miranda (2012, tomo 31, p. 78), trata-se de ato pelo qual "se desinveste alguém, renunciante, de direito, pretensão, ação ou exceção de que é titular". A renúncia da herança é, no entendimento do autor deste artigo, ato jurídico stricto sensu e não receptício - porque não depende do assentimento de qualquer pessoa -, pelo qual o herdeiro ou o legatário declara não aceitar, repudia, a herança ou o legado. Não há criação de qualquer direito sucessório ao renunciante, que é tido como se nunca tivesse herdado. Cahali (CAHALI; HIRONAKA, 2007, p. 76) sumariza a renúncia como "a antítese da aceitação".

\subsection{Relevância do instituto}

$\mathrm{Na}$ atual ordem jurídica, o instituto da renúncia da herança pode causar certa estranheza. Não seria absurdo se perguntar por que alguém abdicaria do direito de receber herança em uma época em que este vocábulo é fortemente associado a acréscimo patrimonial sem esforço algum por parte do herdeiro. Isto nem sempre foi assim.

Até a entrada em vigor do Código Civil de 1916, os herdeiros que aceitassem a herança a aceitavam em sua totalidade, ou seja, passavam a ser titulares de todos os ativos, mas também de todos os passivos deixados pelo falecido. Se o de cujus tivesse deixado mais dívidas do que bens, os herdeiros acabariam pessoalmente obrigados a quitá-las, com o seu próprio patrimônio. Desse modo, dependendo do passivo, aceitar 
a herança poderia levar o herdeiro à condição de devedor de dívidas sequer contraídas por ele. Naquele tempo, renunciar à herança era a alternativa mais simples para livrar o renunciante de responder pelas dívidas deixadas pelo autor da herança. A segunda alternativa seria aceitar a herança, mas invocando a condição de benefício de inventário, para, aí sim, responder apenas até os limites da força da herança. Esta aceitação, contudo, era condicional, e só seria eficaz se o ativo da herança superasse o passivo (HIRONAKA; 2003, p. 112-113).

O Código Civil de 1916 transformou a faculdade do benefício de inventário em determinação legal obrigatória. A partir de então, o herdeiro deixou de responder por encargos superiores à força da herança. O benefício de inventário previne a confusão dos patrimônios do defunto e do herdeiro. Seria exatamente esta separação entre o acervo sucessório e o patrimônio do herdeiro a fundamentação técnica do instituto (GOMES, 1986, p. 26).

É interessante mencionar, a título de curiosidade, que há, na atualidade, ordenamentos jurídicos em que o benefício de inventário continua não sendo determinação legal. No direito espanhol, vale a regra que esteve vigente no Brasil até a entrada em vigor do Código Civil de 1916. Preceitua o art. 998 do Código Civil Espanhol que "la herencia podrá ser aceptada pura y simplemente, o a beneficio de inventario”. Com a crise que tomou conta do país nos últimos anos e o consequente endividamento da população, o número de renúncias cresceu cerca de $110 \%$ entre 2007 e 2012. Muitos espanhóis preferem renunciar à herança para escapar das dívidas deixadas pelo falecido, bem como para evitar pagar a pesada carga tributária incidente sobre a transmissão do patrimônio. ${ }^{10}$

De volta ao direito brasileiro, é inegável que o reflexo da adoção da regra trazida pelo art. 1.587 do Código Civil de 1916 e mantida pelo art. 1.792 do atual Código Civil foi a inegável diminuição dos casos concretos de renúncia de herança. Mas ainda assim persistem algumas motivações suficientes para que as pessoas renunciem à herança. Em determinados casos, os bens deixados pelo falecido podem não representar estímulo suficiente para que o herdeiro aceite a herança, tendo em vista todas as obrigações advindas da aceitação, tais como o pagamento de legados, o cumprimento de encargos e o recolhimento de imposto de transmissão causa mortis.

Há também as renúncias motivadas por razões de foro íntimo do renunciante, que, por exemplo, pode não se sentir à vontade ou até mesmo digno de aceitar os bens a depender da relação pessoal tida com o de cujus. Os casos mais comuns, contudo, são aqueles em que o herdeiro em melhores condições econômicas renuncia à herança por

10 Neste sentido, vale a leitura de reportagem jornalística publicada no website da BBC em 28 de maio de 2013, intitulada "Crise econômica faz espanhóis rejeitarem heranças". Disponível em: < http://www.bbc. com/portuguese/noticias/2013/05/130528_espanha_herancas_fn>. 
caridade, porque sabe que, deste modo, o quinhão repudiado voltará ao monte mor e será redistribuído entre os outros herdeiros em situação financeira mais delicada.

\subsection{Características da renúncia}

Diferentemente da aceitação, a renúncia só admite forma expressa e nunca se presume. E mais, prevê o art. 1.806 do Código Civil que deve a renúncia constar expressamente de instrumento público: escritura lavrada por tabelião competente, ou termo judicial, a ser lançado nos autos de inventário. Tamanha solenidade que reveste o ato, e de cuja eficácia depende, "dá importância que a lei, no intuito de assegurar a liberdade do renunciante, de garantir a autenticidade de sua declaração e de chamar sua atenção para a relevância da atitude que está tomando, lhe dá” (RODRIGUES, 1977, v. 7, p. 33).

Ao exigir essa formalidade qualificada para a prática do ato, a lei dá ao renunciante a oportunidade de refletir antes de declarar sua vontade de renunciar à herança. Quem decide ir a um tabelião ou ao magistrado do processo de inventário para renunciar deve estar ciente da relevância do ato. Vale, contudo, mencionar que nem a validade nem a eficácia da renúncia estão condicionadas a qualquer motivação. O renunciante não precisa expor seus motivos para renunciar, basta fazê-lo.

A importância do ato de repudiar a herança exige que o agente seja plenamente capaz. Aqui, acentua a doutrina, não se refere a uma capacidade meramente genérica para praticar os atos da vida civil, mas a capacidade específica para alienar. Para que o incapaz renuncie, seu representante legal deve requerer autorização judicial prévia, ouvido o Ministério Público. A doutrina entende que os relativamente incapazes podem renunciar se estiverem assistidos por seus representantes legais (HIRONAKA, 2003, p. 121).

O momento para o exercício da renúncia é sempre posterior à abertura da sucessão. Antes da morte do autor da herança, é defeso ao futuro sucessor renunciar à herança, porque o direito hereditário sequer terá nascido até o falecimento do sucedido. A renúncia prematura importaria em pacto sucessório, vedado pelo art. 426 do Código Civil. ${ }^{11}$

Conforme já antecipado, assim como a aceitação, a renúncia é irrevogável, não receptícia, não pode ser sob condição ou termo e não se admite que seja exercida sobre apenas parcela da herança.

A doutrina costuma explicitar a diferença entre a renúncia abdicativa e a renúncia translativa. A renúncia abdicativa vem sendo estudada ao longo deste artigo e é o

11 Diz o art. 426 que: "não pode ser objeto de contrato a herança de pessoa viva". 
ato jurídico unilateral pelo qual o herdeiro simplesmente rejeita a herança e deve respeitar os efeitos legais de sua decisão.

A renúncia translativa, ou renúncia in favorem, é o nome dado para a situação em que o herdeiro aceita a herança e, em seguida, a transfere para outra pessoa. Não se está, aqui, diante do instituto da renúncia, mas sim do instituto da cessão de direitos, que implica duas transferências patrimoniais: em primeiro lugar, o herdeiro aceita a herança e passa a ser titular de seu quinhão hereditário. Em seguida, cede referido quinhão para terceira pessoa. Se a cessão for onerosa, corresponderá a uma compra e venda e se for gratuita, a uma doação (TARTUCE; SIMÃO, 2013, p. 45). Aliás, a hipótese de cessão de herança é inclusive tipificada pelo art. 1.793 do Código Civil, que preceitua o seguinte: “ $O$ direito à sucessão aberta, bem como o quinhão de que disponha o co-herdeiro, pode ser objeto de cessão por escritura pública".

A relevância de se fazer esta distinção é eminentemente tributária. Na hipótese de renúncia abdicativa, não haverá incidência dos impostos de transmissão inter vivos, porque se trata de ato unilateral e não há, aqui, transmissão de propriedade ou de domínio útil de bens. Já na hipótese de renúncia translativa, há efetiva cessão de propriedade por negócio jurídico bilateral, que pressupõe a aceitação do beneficiado. Não há dúvidas, portanto, da incidência do imposto de transmissão inter vivos no caso da intitulada renúncia translativa. A maioria dos casos envolvendo renúncia que são levados ao judiciário versa justamente sobre a discussão quanto à ocorrência, no caso concreto, de renúncia abdicativa ou de renúncia translativa e da incidência do imposto de transmissão inter vivos, se comprovado se tratar da segunda situação.

\subsection{Efeitos da renúncia}

Os efeitos da renúncia são retroativos ao momento da abertura da sucessão. Aquele que renuncia à herança é tido como se nunca tivesse sido herdeiro, ou, no magistério de Itabaiana de Oliveira, "como se tivesse falecido antes do autor da herança" (OLIVEIRA, 1952, v. 1, p. 106). O herdeiro é excluído da herança de forma ampla e definitiva. Em razão disto, os herdeiros do renunciante não herdam por representação, porque, se o renunciante é considerado como inexistente para efeitos sucessórios, não faria sentido que seus herdeiros pudessem aceitar a herança em seu lugar.

Operada a renúncia na sucessão legítima, o quinhão originalmente destinado ao renunciante é devolvido ao monte mor para ser acrescido aos quinhões dos demais herdeiros de mesma classe, grau e linha do renunciante. ${ }^{12}$ Sendo o renunciante o único

12 Aqui, inspirados pela lição de José Luiz Gavião de Almeida, Tartuce e Simão (2013, p. 50-52) frisam que a lei estaria incompleta, porque não menciona expressamente que deveria se respeitar, além da classe, o grau 
herdeiro de sua classe, ou tendo todos os coerdeiros renunciado, a herança passa aos herdeiros do grau seguinte dentro da mesma classe e, se inexistentes estes, aos herdeiros da classe subsequente. ${ }^{13}$ Os herdeiros da classe subsequente não virão à sucessão por representação, mas sim por direito próprio e por cabeça, ou seja, o quinhão do renunciante será dividido igualmente por quantos forem os sucessores da classe seguinte. ${ }^{14}$

Tratando-se de renúncia de herdeiro testamentário ou de legatário, será preciso verificar no caso concreto se o testador não previu outro destino para o quinhão ou bem. Pode ser que o testador tenha deixado expressa previsão de substituição do renunciante por outro herdeiro ou legatário, ou a possibilidade de acrescimento do quinhão do renunciante no monte de um ou mais herdeiros testamentários. Se nada disso tiver sido previsto pelo testador, então o quinhão do herdeiro testamentário ou o bem do legatário renunciantes também comporão o monte mor da legítima para serem distribuídos entre os herdeiros necessários.

Preceitua o art. 1.813 do Código Civil que: "quando o herdeiro prejudicar os seus credores, renunciando à herança, poderão eles, com autorização do juiz, aceitá-la em nome do renunciante". O prejuízo aos credores restará verificado se o devedor não tiver patrimônio suficiente para quitar suas dívidas e, ainda assim, optar pela renúncia da herança, impossibilitando o adimplemento de suas obrigações perante estes terceiros. Note-se que poderão aceitar a herança em nome do renunciante os seus credores e não os credores do falecido. Estes últimos poderão se habilitar no inventário para perseguir o pagamento das dívidas deixadas pelo autor da herança.

Embora a situação lembre o instituto da fraude contra credores, não se pode fazer confusão. No caso de renúncia da herança, no momento da constituição do crédito, o credor do herdeiro ainda não contava com o patrimônio que o herdeiro poderia vir a herdar e que sequer dispunha até a abertura da sucessão. Além do mais, a regra prevista no art. 1.813 do Código Civil é mais vantajosa para os credores do renunciante, pois não se exige a demonstração da intenção de prejudicar os credores (consilium fraudis), nem o ato dependerá de determinação judicial para ser declarado inválido.

Aqui não se ataca a validade da renúncia. Além disto, será o ato completamente eficaz quanto aos coerdeiros e aos sucessores do renunciante, e tão somente

e a linha do renunciante. Com alguns exemplos, os autores mostram que a interpretação literal da lei poderia levar a divisões de herança que contrariariam o espírito do legislador.

13 Este mecanismo está disciplinado pelos arts. 1.810 e 1.811 do Código Civil.

14 É bastante didático o exemplo dado por Tartuce e Simão (2013, p. 49): "se o falecido deixa dois filhos e três netos, e o falecido não era casado nem vivia em união estável, caso todos os filhos renunciem à herança, os três netos receberão por direito próprio e não por representação". No exemplo dado, dois netos eram filhos de um dos renunciantes e o terceiro, era filho do outro renunciante. Ainda assim, cada neto ficaria com um terço da herança do falecido. 
ineficaz perante os credores, que se sub-rogarão no direito de receber a herança, no limite dos créditos. Eventual saldo remanescente voltará ao monte mor e será partilhado entre os demais herdeiros da mesma classe (CAHALI; HIRONAKA, 2007, p. 80).

Os credores têm até 30 dias do conhecimento da renúncia para se habilitar no inventário, sob pena de decadência. Se o processo de inventário tiver sido encerrado e a partilha realizada, os credores perdem essa prerrogativa, porque os bens já serão patrimônio individualizado dos outros herdeiros.

A lei é silente quanto à possibilidade de sub-rogação dos credores do legatário que renunciar ao legado. Simão, Tartuce e Gavião de Almeida entendem pela possibilidade de aplicação analógica da regra do art. 1.813 do Código Civil (TARTUCE; SIMÃO, 2013, p. 54). Giselda Hironaka e Washington de Barros Monteiro são contrários a esta aplicação analógica, porque contra a vontade do testador não se deveria fazer benefício (HIRONAKA, 2003, p. 141). Parece mais acertada a extensão da possibilidade de sub-rogação aos credores do legatário renunciante. Uma interpretação tão literal e restritiva do art. 1.813 não faria sentido.

\subsection{Renúncia x outorga conjugal}

Ponto bastante controvertido na doutrina e também na jurisprudência diz respeito à necessidade ou não de outorga conjugal para que a renúncia da herança seja considerada válida, salvo no caso da separação absoluta de bens, em que a autorização do cônjuge será sempre dispensada.

Grande parte da doutrina vê pertinência na aplicação da regra trazida pelo art. 1.647, inciso I, do Código Civil, por dois argumentos principais: (i) a sucessão aberta é considerada bem imóvel, nos termos do art. 80, inciso II, do Código Civil; e (ii) a renúncia da herança seria ato de disposição, equivaleria a uma alienação de bem imóvel ou, ao menos, a uma diminuição patrimonial por não acrescer os bens da herança ao patrimônio do renunciante. Entendem deste modo os seguintes juristas: José Fernando Simão, Flávio Tartuce, Zeno Veloso, Sílvio Venosa (TARTUCE; SIMÃO, 2013, p. 47), Hironaka (2003, p. 122), Francisco Cahali (CAHALI; HIRONAKA, 2007, p. 79) e Oliveira (1952, p. 16).

Uma segunda corrente advoga pelo descabimento da exigência de outorga conjugal em caso de renúncia de herança. O entendimento aqui é de que a renúncia não importaria, essencialmente, em ato de disposição ou alienação de bem imóvel, mas de não aceitação da herança. Pelo contrário, por meio do repúdio à herança, o herdeiro busca justamente se livrar desta condição, não estaria o herdeiro dispondo de qualquer coisa, porque sequer seria titular do direito.

Realmente, o próprio conceito de renúncia se afasta consideravelmente do conceito de alienação. Mais uma vez, cabe recorrer ao preciosismo técnico de Miranda 
(2012, tomo 3, p. 216), que explica que a renúncia será sempre abdicativa, nunca translativa; "se o fosse, confundir-se-ia com a alienação, a transferência. Alguém pode ter de receber a renúncia e aproveitar-lhe a si, ou a outrem, a renúncia; mas a renúncia, simplesmente abdicativa, como é, só indiretamente aproveita a outrem. Quem renuncia só perde, não transmite".

Antonio Junqueira de Azevedo recorre a uma interpretação histórica dos dispositivos que regulam a matéria para concluir pela desnecessidade de anuência do cônjuge do renunciante. Lembra o professor que a redação original do art. 242, inciso IV, do Código Civil de 1916 era muito clara ao proibir que a mulher casada aceitasse ou repudiasse herança ou legado sem autorização do marido. Referido inciso foi eliminado do art. 242 por força do Estatuto da Mulher Casada, que promoveu importantes avanços para concretizar a ideia de igualdade absoluta entre a mulher e o homem. Nas palavras de Junqueira de Azevedo (2004, p. 355-356):

Ora, o Código Civil, quanto à aceitação ou renúncia da herança, dispensou a anuência do cônjuge, de início, para o marido, e depois, também para a mulher, entre outras razões, porque, justamente, no ser ou não herdeiro, nem tudo é somente patrimônio; há todo um envolvimento de foro íntimo, personalíssimo, toda uma parte afetiva, claramente sentida, quando se diz que 'fulano é o herdeiro', com conotação de continuidade entre pessoas. Não é lógico, por exemplo, pleitear, no caso, suprimento de consentimento; 'herdeiro' não significa somente 'sucessor de bens'. Paralelamente, a frase 'cônjuge de herdeiro não é herdeiro' dá também todo o sentido de por que sua anuência é dispensada na aceitação ou renúncia da herança; o cônjuge não deve anuir porque ele nada tem que ver com o caráter pessoal da sucessão entre o de cujus e o herdeiro.

De fato, o art. 235 do Código Civil de 1916, que impunha a necessidade de autorização da mulher para que o marido pudesse praticar determinados atos, nunca exigiu outorga uxória para o exercício da aceitação ou da renúncia da herança. A redação original do art. 242 impunha as mesmas restrições expressas para a mulher casada e mais diversas outras, entre as quais, a de submeter a aceitação ou a renúncia à herança à aprovação do marido - conforme já mencionado, o incisivo IV foi revogado posteriormente.

Quando a legislação quis exigir outorga conjugal para o exercício da renúncia, o fez expressamente. Neste sentido, vale colacionar trecho de voto do magistrado Claudio Godoy em recente acórdão proferido pelo Tribunal de Justiça de São Paulo, em que o julgador expôs sua opinião quanto à matéria de forma extremamente aprofundada: ${ }^{15}$

15 Apelação Cível n. 9000004-03.2005.8.26.0132/TJSP, Relator o Desembargador Claudio Godoy, julgado em 
Depois, também não se deve olvidar que previsão restritiva de direitos não pode ser interpretada de forma ampliativa, para abarcar o que não é, exatamente, nem uma alienação ou gravação, nem mesmo de um bem de raiz, considerada imóvel a herança por determinação legal. A disposição expressa vigente depois do Estatuto e mesmo no atual CC (art. 1.647, I) é de exigência de vênia conjugal apenas para alienar e gravar de ônus real os bens imóveis. Diferente de outros sistemas que expressamente, aí sim, reclamam outorga do cônjuge para repudiar herança ou legado (v.g. art. 1.683.2 do CC português).

Parece descabida a aplicação da exigência feita pelo art. 1.647, inciso I, do Código Civil no tocante à renúncia de herança. $\mathrm{O}$ melhor entendimento é aquele que conclui pela desnecessidade de outorga conjugal para que a renúncia se opere de forma válida. ${ }^{16}$

Conclusão

O aprofundamento do estudo da aceitação e da renúncia da herança permite traçar algumas conclusões quanto ao tema. Primeiramente, é importante entender que o sistema brasileiro adotou dois momentos envolvendo a transmissão da herança do de cujus para os herdeiros. A transmissão ocorre de maneira automática no momento da sucessão, por meio de uma presunção legal e é confirmada, em um segundo momento, pela aceitação declarada por cada um dos herdeiros. Conceder ao herdeiro a oportunidade de aceitar ou não a herança é muito importante, porque ninguém é obrigado a herdar.

Ficou evidenciado, também, que tanto a aceitação quanto a renúncia da herança são melhor enquadradas na categoria dos atos jurídicos stricto sensu, porque ao herdeiro aceitante ou renunciante não cabe modular os efeitos e o conteúdo de sua escolha.

Mesmo com a mudança operada pelo Código Civil de 1916, pela qual o benefício de inventário passou a ser a regra legal, a renúncia de herança continua tendo relevância no direito brasileiro. Dentre outros motivos, recorre-se ao instituto com o intuito de favorecer coerdeiros em situação financeira menos favorecida.

Não parece fazer sentido exigir outorga do cônjuge do herdeiro para que a renúncia seja reputada como válida. A evolução legislativa retirou esta restrição para a mulher casada, que, ressalte-se, nunca foi restrição para o homem casado. Comparar

21/07/2015.

16 Esta também é a posição de Diniz (2014, p. 63), José Luiz Gavião de Almeida (ALMEIDA, apud TARTUCE; SIMÃO, 2013, p. 47) e Washington de Barros Monteiro (MONTEIRO, apud CAHALI; HIRONAKA, 2007, p. 71). 
renúncia com alienação seria tratar como similares dois institutos essencialmente diferentes.

São Paulo, 20 de maio de 2017.

\section{Referências}

BORGHI, Hélio. Da renúncia e da ausência no direito sucessório. São Paulo: Leud, 1977.

CAHALI, Francisco José; HIRONAKA, Giselda Maria Fernandes Novaes. Direito das sucessões. 3. ed., rev., atual. e ampl. da 2. ed. do Curso avançado de direito civil - v. 6. São Paulo: Revista dos Tribunais, 2007.

DINIZ, Maria Helena. Curso de direito civil. 28. ed. São Paulo: Saraiva, 2014. v. 6.

GOMES, Orlando. Direito das sucessões. 6. ed. Rio de Janeiro: Forense, 1986.

HIRONAKA, Giselda Maria Fernandes Novaes. Morrer e suceder: passado e presente da transmissão sucessória concorrente. 2. ed. rev. São Paulo: Revista dos Tribunais, 2014.

. Comentários ao código civil. In: JUNQUEIRA DE AZEVEDO, Antonio (Org.). Comentários ao código civil. São Paulo: Saraiva, 2003. v. 20.

JUNQUEIRA DE AZEVEDO, Antonio. Estudos e pareceres de direito privado. São Paulo: Saraiva, 2004.

MIRANDA, Francisco Cavalcanti Pontes de. Tratado de direito privado: parte geral. São Paulo: Revista dos Tribunais, 2012. Tomo 3.

. Tratado de direito privado: parte especial. São Paulo: Revista dos Tribunais, 2012. Tomo 31.

MONTEIRO, Washington de Barros. Curso de direito civil. 30. ed. São Paulo: Saraiva, 1995. v. 6.

OLIVEIRA, Arthur Vasco Itabaiana de. Tratado de direito das sucessões. 4. ed. São Paulo: Max Limonad, 1952. v. 1.

RODRIGUES, Silvio. Direito civil. 7. ed., São Paulo: Saraiva, 1977. v. 1.

TARTUCE, Flávio; SIMÃO, José Fernando. Direito civil. Direito das Sucessões. 6. ed. rev. e atual. São Paulo: Método, 2013. v. 6.

VELOSO, Zeno. Renúncia de herança não é cessão. Belém do Pará, 2008. Disponível em: <http:// www.luisbuarque.com.br/wp-content/files_mf/1360950452Renunciadeherancaecessao.pdf>. 